\title{
Judith Gloppen
}

\section{The Strategic Use of Service Design for Leaders in Service Organizations}

\begin{abstract}
There is a growing interest among scholars, practitioners and organizations as to how design may benefit management, particularly when this happens in a service context. In this exploratory qualitative study, I investigate such a multi-disciplinary intersection with the aim of better understanding how service design may be of value for leaders in service organizations on a strategic level. The research draws on a service design approach called AT-ONE. Addressed are ways that the strategic use of service design may influence attitudes and transformation in service organizations. The study presents views from the designers, implementers and users of this approach, supported by participant observation and interviews. This was done through in-depth qualitative interviews with the AT-ONE project members and designer, with the service design professional company involved, and leaders from the businesses participating in the project and workshop sessions. These were observed by the researcher. Drawing on the findings of this exploratory study, some implications for the field of service design management at the corporate level are offered.
\end{abstract}

Keywords: Service Design, Design Management, Service Innovation, Service Design Leadership.

\section{Introduction}

The transition from manufacturing economy to service economy has led to a shift in business agenda from goods-oriented organizations to service-oriented organizations. Multiple design disciplines are involved in designing services. The complexity of the design of these services demands close collaboration between designers and business leaders to conceptualize services that are perceived as valuable by users, organizations, and other stakeholders. To a considerable degree, this calls for cross-disciplinary collaboration and orchestration in the form of the shaping of a service design leadership approach at top corporate levels. A service design leadership approach is one that exploits synergies from interdisciplinary perspectives (design and business leadership) in the context of providing suitable services. Insights from design management provide some means to understanding the development of customer-centric service innovations. However, this understanding may be further supported by looking more closely into an approach that focuses on the front end of innovation in the emerging field of service design. The front end is where ideas are created and assembled into concepts that may influence the direction and scope of the organization. In other words, new service concepts may lead to strategic decisions that are likely to affect the long-term direction and, thereby, the future strategy in service organizations. Service organizations may be both manufacturing companies that have service elements to their core products and organizations where service is the core product and where tangible products may be needed to deliver the service.

Although design is increasingly viewed as an important strategic resource for innovation and competition, it appears that this perception is stronger when it comes to products than services. Research on the value of service design as a strategic resource for service organizations still remains relatively sparse. A strategic resource is one that is geared 
towards providing clearer directions for a business. The main question this article investigates is how service design may be implemented at the level of strategy to support leaders of service-oriented organizations to shape innovative services. The qualitative study is exploratory in character. It looks into how service design may be employed, strategically, to influence the overall scope and direction of a service organization at a broad corporate level, as well as future objectives for various business units. On the operational level, the strategic use of service design influences how the service is delivered on a day-to-day basis. For service design to be an important means of enhancing competitiveness and growth, there is a need for it to be treated as a potential strategic resource and the basis of sustainable competitive advantage in the future. Shaping innovative services so that they arrive at this desired future demands a customer-centric leadership that draws on both design and corporate strategy.

To understand service design in a business context, recent scholarly discussions on service perspectives and emerging literature on service design are drawn upon (e.g. Clatworthy, 2011). Further, the changing role of designers is discussed. This is conducted in respect to the evolution of the field of design management in response to the existing dominance of the service sector in many Western economies. Connected to this is what kind of impact service design may have on the field of design management to integrate professional service designers in the development of services.

This study is part of a project called AT-ONE on improving the early stages of service innovation. The study uses the project context to expose on how we may better understand connections between service design, design management and the role of leaders in customercentric organizations. The project has developed a service design method that aims at improving the early stages of service innovation through the integration of design into a structured innovation process. The method consists of workshops that use five different lenses - Actors, Touchpoints, Offering, Needs and Experience - for enabling a well-connected approach to designing innovative services in a collaborative process between designers and industry partners. The project, approach and method are covered below.

A number of mixed methods are taken up. This has included interviews with the ATONE project and workshop designer, one service design professional linked to the project, one-on-one interviews with leaders in two organizations attending the AT-ONE workshops, participant observation and attendance at workshops.

In order to explore service design in a strategic business context, in the analysis of the data, the following key areas are examined: a) multi-disciplinary collaboration, b) visualization, c) service perspective vs. product perspective and d) awareness of the value of service design through experience. In this regard, the study poses questions for both professionally trained designers and the role of leaders in service organizations. Furthermore, it raises issues about the implications of the role of design management in the service economy. This micro-study may lead to considering a new form of customer-oriented perspective when shaping innovative services and transformative orientation of using service design strategically in business. This is important because our understanding of strategy needs to be expanded to include both an elaborate view of design management along with the role of service design in helping meet the roles of leaders in customer-oriented strategy development.

\section{Theoretical Frameworks}

This section presents a framework for understanding how a service design approach to problem solving may be used strategically to shape innovative services. From a design 
management view that draws on the discourse of design as well as on the discourse of management, I draw together viewpoints on the shift towards a service perspective in business as well as the evolution of the role of design and design management in relation to this service perspective.

\section{A Service Perspective as a Strategic Approach}

Although design has long been recognized as a driver for innovation within product design, only more recently has it been acknowledged as such in the design of services. Today, broadly, service design is used to refer to methods and processes used by professionally trained designers applied to the development of services (Mager, 2004). Development of services includes the design of a system of touchpoints (points of contact) between the service provider and the user. These series of touchpoints together constitute a service journey, which may also be referred to as a customer journey. The interrelated system of touchpoints requires orchestration in order to create service offerings that are perceived to be valuable by the user. The development of each touchpoint and their orchestration demand a strategic leadership approach that may benefit from a collaboration between leaders in service organizations and service designers.

Gummesson (2007) argues that "there is no generally accepted and complete definition of services. Services could basically be referred to as dynamic activities and processes, while goods are static things" (p. 116). The service-dominant logic (S-D logic) perspective, introduced by Vargo and Lusch (Vargo \& Lusch, 2004, 2008) in the field of marketing, views service provisions rather than goods as the basis for economic and social exchange. The researchers argue that "the orientation has shifted from the product to the consumer" $(2004, \mathrm{p}$. 15). Likewise, Normann (2007) argues that the notion of service logic (to use his term) "forces us to shift our attention from production to utilization, from product to process, from transaction to relationship" (p. 98). Involving the customer as a co-creator of value in the value-creating process is central to S-D logic (Lusch \& Vargo, 2006). In relation to innovation, the S-D logic provides a theoretical perspective that demands a shift towards a value-in-use perspective as well as shift from a company perspective to a consumer-centric view (Michel, Brown, \& Gallan, 2008). One may ask this: how will applying strategic use of service design to the S-D logic perspective empower design of desirable service innovations?

Innovation in service design is strongly shaped by the need to pay attention to the customer's point of view. This viewpoint refers to how the perspective of the customer is given preference in the development of every touchpoint of a service journey. A way to obtain this is to apply specialized knowledge and competences to create benefits and perceived value when customers use a service (Edvardsson, Gustafsson, Kristensson, Magnusson, \& Matthing, 2006). One of these specialized competences is service design. In a business context, "Design is the process of seeking to optimize consumer satisfaction and company profitability through the creative use of major design elements..." (Kotler \& Rath, 1984, p. 17). In order to achieve an optimal design outcome, Gloppen (2010) argues that leaders should exploit the synthesis of the specialized competences of service designers with business competences.

When designing services, a strategic approach that focuses on how to create service offerings thought to be valuable by customers or consumers is needed. "Companies need to develop the service activities and components of the overall customer offering, which implies realizing a service perspective as a strategic approach" (Edvardsson, et al., 2006, p. 3). More specifically, "A strategy is the set of actions through which an organization, by accident or 
design, develops resources and uses them to deliver services or products in a way which its users find valuable, while meeting the financial and other objectives and constraints imposed by key stakeholders" (Haberberg \& Rieple, 2008, p. 6). Edvardsson et al. (2005) argue that "Looking at service as a perspective on value creation through the lens of the customer may add to future understanding of the service approach" (p. 118). Designing services from the customer's or user's point of view is one of the core competences of professional designers. Thereby, business leadership may benefit from a service design approach when developing an organization to meet user needs (conscious and unconscious) in order to create customer experiences perceived as valuable by users.

\section{The Evolution of the Role of Design and Designers Towards Design of Services}

The designer's role is evolving and shifting as a consequence of the service sector being dominant in most developed economies. In product development, the role of design has advanced from design being considered a sub-process in the 1990s to designers taking on a leadership role in the development of new products (Perks, Cooper, \& Jones, 2005). Scholars are now arguing that regarding design as being about creating objects and experiences is too narrow a perspective, and that there is a need to explore the role design may have at a more strategic corporate level (Cooper, Junginger, \& Lockwood, 2010).

Lately, design thinking - how designers approach problems by use of their methods, processes and attitudes - has aroused interest in the management discourse. "Design thinking occurs at the merger of business and design" according to Johansson and Woodilla (2009, p. 31 ). In relation to how design may contribute to business strategy, Brown (2008) argues that "thinking like a designer can transform the way you develop products, services, processes and even strategy" (p. 85). Liedtka (2000) links strategic thinking to design thinking by arguing that they are both abductive in nature. Abductive refers to the logic of what might be. Conversely, deductive and inductive logic build, respectively, from premises and via bottomup processes. Liedtka argues that strategic thinking and design thinking are both concerned with what might be and how to realize the desired future state. Similarly, Martin (2009) makes the point that "The design-thinking organization applies the designers' most crucial tool to the problems of business. That tool is abductive reasoning" (italics in original) (p. 62).

The design of services concerns business strategy at the corporate level of a 'design thinking' organization in the sense that everyone in a service organization is part of what together shape the customer or end-user's total experience of the service offering. This experience is affected both by what is happening in an organization's back- and front-office, where direct interaction with users takes place throughout the service journey.

Service designers' influence on a corporate level extends to conceptualization and implementation of services as complex and pluralistic service journey 'products' that require a different mindset than designing a single product. Holmlid (2007) argues,"With service design the challenge lies in its business, innovation and strategy focus, and the holistic approach of setting other design disciplines into a wider social and action context" (p. 7). Due to the holistic perspective and the complexity involved in designing services, design management needs to better consider cross-disciplinary collaboration and orchestration.

\section{The Evolution of Design Management Towards the Service Economy}

The field of design management has been influenced by changes in society from the industrial economy toward today's service economy. The discourse of management has shifted from scientific management with a focus on standardization and mass production to service 
management with a focus on "teamwork, inter-functional collaboration and interorganizational partnership" (Grönroos, 1994, p. 9). Cooper et al. (2010) explain design management as "the ongoing management - and leadership - of design organizations, design processes, and designed outcomes (which include products, services, communications, environments and interactions)" (p. 60). The Design Management Institute (DMI), ${ }^{1}$ which is the leading body of knowledge within the field of design management, states that

The scope of design management ranges from the tactical management of corporate design functions and design agencies, including design operations, staff, methods and processes - to the strategic advocacy of design across the organization as a key differentiator and driver of organizational success. It includes the use of design thinking — or using design processes to solve general business problems. ${ }^{2}$

As design management moves towards managing the design of innovation and services (Cooper, et al., 2010), it may influence and envision future scenarios and enable innovation as part of a design leadership role at the corporate level (Lockwood, 2010a). According to Turner and Topalian (2002), the central characteristics of design leadership include how design may contribute to corporate strategy by being concerned with visions and desired directions for the future.

In a service context, design leadership may be termed service design leadership (Gloppen, 2010). Drawing on Turner and Topalian, I argue that service design leadership demands understanding of how service design may contribute to corporate strategy. This includes taking advantage of synthesizing design and business competences in developing service innovations that are perceived as valuable from the customer's as well as from the service provider's point of view.

Service design is clearly still being defined in and from its emerging practice. To explore the question of what service design is, the Service Design Network (sdn) was formed in 2004. ${ }^{3}$ The sdn consists of an international mix of academics, design practitioners and businesses (service providers). The network is growing rapidly, much due to the yearly $s d n$ Service Design Conference. Research shows that 'designing of services cannot easily or usefully be separated from design management and from the management and operation of services' (Kimbell, 2010, p. 64). Arguing that no strong academic forum currently exists for design management, the first Cambridge Academic Design Management Conference $(C A D M C)^{4}$ is taking place in 2011. The organisers consider research in the emerging fields such as service of particular interest, among other topics.

In line with the evolution of the role of design, design management has developed from project level to include the corporate level (Lockwood, 2010b), where design thinking may influence an organization's way of doing business (Borja de Mozota \& Kim, 2009; Cooper, et al., 2010). The contribution of design thinking to strategy development has gained interest as part of the design discourse as well as the management discourse. The recent focus on design thinking - among researchers, (Cooper, et al., 2010; Lockwood, 2010a; Rylander, 2009), design professionals (Brown, 2008, 2009; Løvlie, Downs, \& Reason, 2008), business scholars (Liedtka, 2000; Martin, 2009), business magazines like Business Week and Harvard Business Review - is accentuating the value of design into more untraditional design areas. These include health services, organizational strategy and business transformation. For service design, these emerging domains of interest open up for contribution within areas that 
have not traditionally made extensive use of professionals trained as designers.

\section{Designing for Service Innovations}

The use of design in product innovation has a long tradition. The application of design tools in service innovation has not yet been adopted in the same way (Bessant \& Maher, 2009). Within the field of design management, the S-D logic perspective (Vargo \& Lusch, 2004) raises the issue of how professional designers may contribute to service innovation and value creation. Likewise, how their expertise can be managed and made use of at different levels in service organizations. Boztepe (2007) identifies the need for "developing tools and methods applicable in design practice that would enable designers to be active in enhancing value creation." Lately, a stream of books related to service design methods and tools as well as service innovations have been launched (e.g. Meroni \& Sangiorgi, 2011; Miettinen \& Koivisto, 2009; Stickdorn \& Schneider, 2010). Adopting design methodologies and tools like visual thinking, storytelling and prototyping has been successfully applied in a relatively new business book on business model generation (see: Osterwalder \& Pigneur, 2010). This book is based on Osterwalder's PhD thesis (Osterwalder, 2004) according to Osterwalder (conversation with the author May 19, 2011). The book is an example of how business thinking and design thinking may be combined to benefit leaders in service organizations aiming to shape service innovations at the intersection of design and business.

One new method developed to introduce service design to service providers in their process of developing service innovations is the AT-ONE method. It focuses on the front end of service innovation. The front end includes the activities taking place before the more formal development process takes place. More specifically, it concerns the stage where creativity is used to develop ideas and concepts for innovative services. It represents opportunities for both incremental improvements and more radical innovations. The five lenses that are part of the AT-ONE method allow business leaders and designers to take a broad perspective when designing service innovations. The method is further explained below.

\section{Research Methods}

This exploratory micro-study of service design as a strategic resource for service organizations draws on qualitative research methods. It does so to explore how service designers' methodologies and thinking may inform the shaping of strategic approaches to service innovation. The study also probes how leaders in service organizations relate to the service design methods already tailored to workshop style coverage and engagement. The study suggests how observation and in-depth qualitative interviews may enrich our understanding of ways leaders in businesses respond to customer-centric design at the front end of an innovation process aiming to shape new or improved services.

The study adopted mixed qualitative methods. These included participative and nonparticipative observation (Ghauri, Grønhaug, \& Kristianslund, 1995) of workshops and faceto face interviews (Robson, 2002). These modes of research were taken up to be able to dig deeper into the perspectives of both the designer and users of the workshops. Qualitative interviews (Kvale, 1996) were also selected as an effective means of eliciting the view of designers of the workshop approach and its actual implementation. These views were important to secure in order to better understand the offering and process given to workshop participants. The participants in the workshops were also interviewed, using semi-structured questions that had been discussed with the research project leader, the workshop designer and 
design professionals behind the workshop as well as related design management, service design and business researchers. The interviews took place in the last year of the three-year project. The reason for this was that the project needed to establish its practices, and I needed time to understand its dynamics. In addition, interviews were carried out with AT-ONE industry partners based on an interview guide developed by this researcher in consultation with related project researchers, thesis advisors and the project leader. This guide covered personal background, attitude towards design and innovation in general and service design and service innovation in particular, and experience gained by co-operating with service designers who participated in the AT-ONE research project. The interview guide was informed by observations by the author in a number of workshops along with insights from a meeting between the project partners in February 2009. Furthermore, the guide drew on the author's own previous professional experience within strategic design management and leadership in a service context.

A series of semi-structured interviews were carried out in November 2009, and January and February 2010. In addition to the industry partners, interviews were conducted with the designer and project leader of the project (Simon Clatworthy), and with a professional service designer participating in the project (Lavrans Løvlie, live|work). The questions were semi-structured and each interview lasted from 50 to 80 minutes. The interviews were taped and transcribed, and, in some cases, translated from Norwegian to English by the author.

It is important to point out that this research was exploratory in character; it used qualitative methods to investigate an experimental workshop-based design innovation process and offers tentative findings and micro-level insights. Although these cannot be widely scaled up, they point to a number of issues, questions and implications for how service design views may be understood and taken up by leaders in service-oriented organizations.

\section{The AT-ONE Approach}

\section{Designing Service Design}

The design of services needs to take into account multi-disciplinary design competences as well as being able to accommodate knowledge and skills from business. Five lenses were selected and are part of the AT-ONE service design approach to facilitate service design from an integrated view. AT-ONE ${ }^{5}$ is a service design method that considers and synthesizes research and practical knowledge from a variety of disciplines within the fields of design, management and innovation to shape service innovations (Clatworthy, 2008). It is based on a collaborative and negotiated development process between designers and service organizations, where designers' methods and processes are tailored to designing services and adapted to corporate strategy. The method focuses on customers' functional and emotional needs and brings design in at the early stages of a service innovation process.

The AT-ONE method was critically constructed by Simon Clatworthy; it drew on his experience as a design educator and researcher. To further develop the method, a research project was established with support from the Research Council of Norway. The project is a collaborative partnership between participants from the service sector, service designers (both professional and students) and academics (both within business and design). The project began in late 2007 and finished at the close of 2010. The partners were invited by the project manager to participate in the AT-ONE research project.

The aim of the project was that by being open to new perspectives, service designrelated service organizations might discover and act on new insights about their current and 
future customers and then use the insight gained to inform and inspire service innovations that create value for both customers and the industry partners.

As a means of mapping a service offering holistically, from the customer's point of view, AT-ONE uses the notion of the 'customer journey' (Clatworthy, 2010). This draws on the service blueprint method introduced by Shostack (1984), derived from service marketing. This mapping of all touchpoints between customers and service provider is carried out in collaboration between service designers and service organizations. One of the core elements of the AT-ONE method is design thinking, of which abductive thinking in one of the key aspects and the way of thinking that is encouraged in the workshops (Clatworthy, 2008). ATONE introduces design, design thinking and design approaches to people who have power within service organizations "with the aim to influence that next time they are in a project they will put design in on an early stage," according to Clatworthy (interview by author November 18, 2009).

The AT-ONE project has designed a specific set of lenses in order to work through a holistic view of innovation challenges given by the industry partners (see Fig. 1). These lenses were arrived at by the project designer drawing on his consultancy experience mainly based on self-service technology for mini-banks and ticket machines as well as future scenarios for television and mobile phones. He was working in multi-disciplinary projects that included designers and experts within psychology, sociology, marketing, business strategy and technology. Frustrated by the main focus on technology and the lack of understanding of the customer, he was inspired by the theory about the experience economy (Pine \& Gilmore, 1999) to extract the essence of what designing services is all about. In the process, he ended up with five main points. Although these do not cover all aspects of service design, they cover the main elements that are often overlooked by the companies, in his experience (interview by author November 18, 2009). The five main points form the basis for the five lenses: Actors refers to new combinations of actors who together provide the service. Touchpoints is to do with the coordination and development of touchpoints between the customer and service provider. Offering refers to the design of what the service actually offers. Needs covers the needs that the service meets and satisfies. Experience concerns the experience that the service gives the customer. Together, the five lenses provide a basis for building and investigating a common understanding between designers and industry partners in the workshop-based process of designing services. However, from a service design leadership point of view, the orchestration of touchpoints is essential, as are linking the five lenses to corporate strategy. 


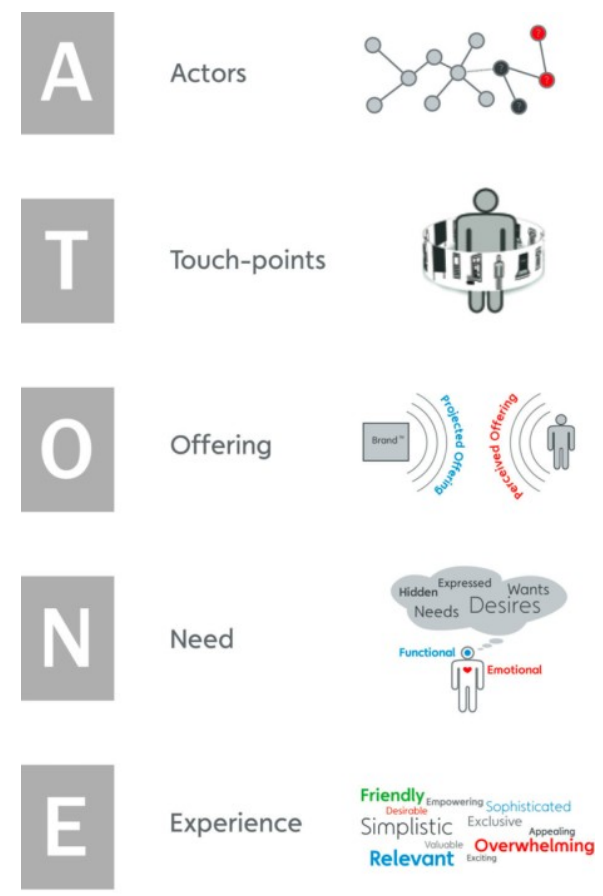

Figure 1. Five 'lenses' for use by multi-disciplinary teams at the front end of the AT-ONE service innovation process. (Illustration from the AT-ONE project.)

\section{The Workshops}

The AT-ONE service design workshops bring together and facilitate multi-disciplinary competence, knowledge and skills from design and business. The industry partners contribute with 'real world' cases, briefs and market knowledge in addition to sharing the company's vision, values and strategies. Service designers contribute with their design methods, creative toolbox, approaches to problem solving and their customer-centric attitude. A core team consisting of the industry partner's project leader in collaboration with a designer develops the design brief, plans the AT-ONE workshops and conducts the final workshop. In the five AT-ONE workshops, several participants from the industry partners attend in collaboration with service designers (Figure 2). These industry participants were leaders from different departments invited by the industry partner's project leader.

The AT-ONE workshop series joins industry partners with designers to jointly generate ideas for service innovations two times a year during the three-year project. Each workshop focuses on one of five main themes: Actors, Touchpoints, Offering, Needs and Experience. Some of the design tools and methods that are used during the workshops include storytelling, visualization, personas, brainstorming and identifying touchpoints between service provider and service user during a service journey.

The AT-ONE workshops consist of three main elements. The first is a theoretical introduction to each of the lenses. Then, there is practical work by designers in collaboration with the AT-ONE industry partners to generate multiple ideas for service innovations. Service designers and industry partners in collaboration then evaluate each idea. The best ideas are brought forward to a closing workshop and developed into the most promising concept ideas. The closing workshop synthesizes the ideas from all workshops into a few main concept ideas 
that are 'evidenced' by visualization and storytelling to a level that can form the basis for judging whether or not to proceed with a concept idea. The idea generation process draws on the 'double diamond' design process model developed by the U.K. Design Council. ${ }^{6}$ This model is divided into four phases: 1) discover, 2) define, 3) develop and 4) deliver. The ATONE method concerns the divergent and convergent stages in phases 1 and 2, as indicated in Figure 2.

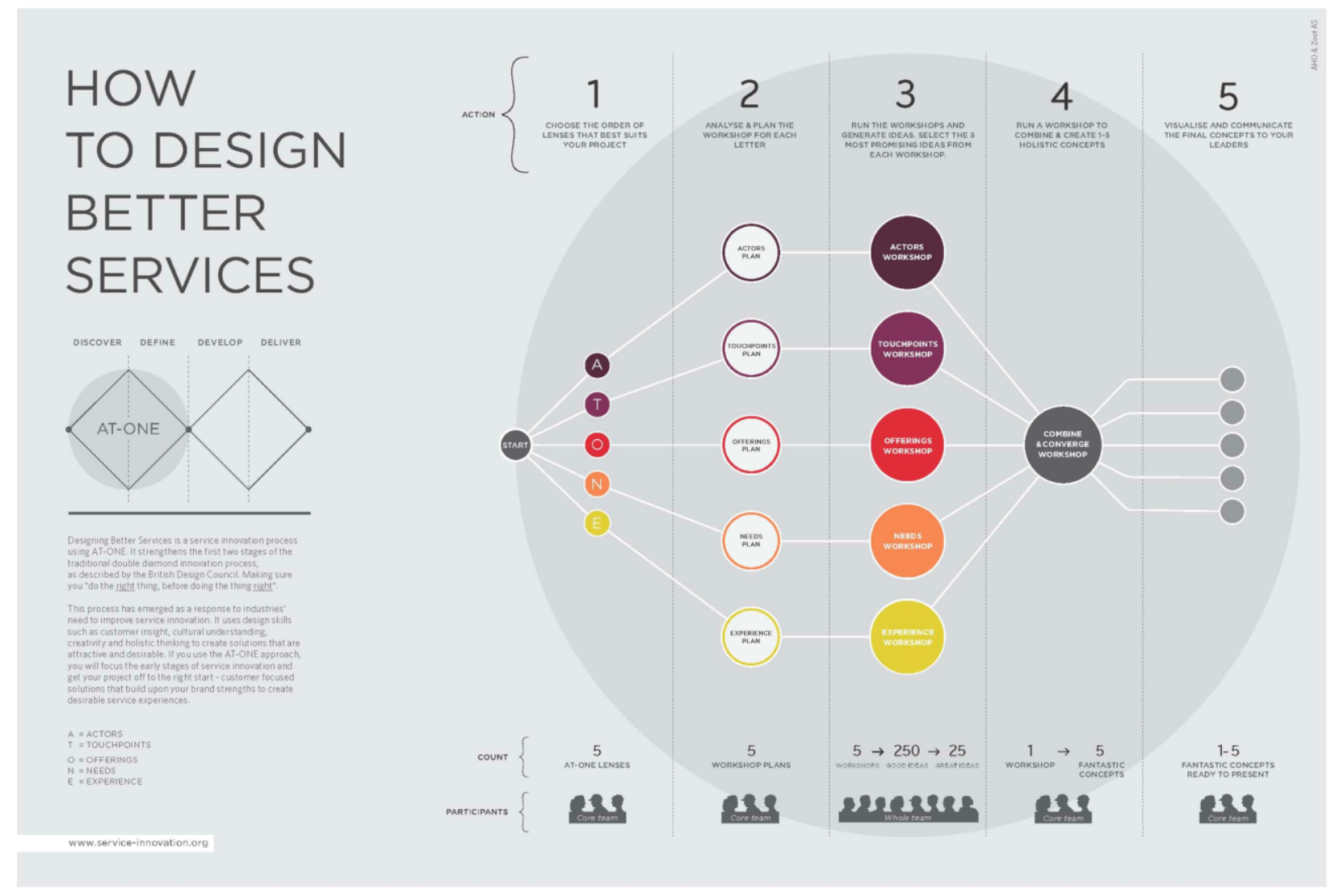

Figure 2. The AT-ONE workshop method for designing new or improved service innovations at the front end of a multi-disciplinary and collaborative innovation process. (Illustration from the AT-ONE project.)

The main purpose of the AT-ONE workshops is to create ideas and concepts at the front end of service innovation. As such, it takes place at an operational level of idea development. However, the five AT-ONE lenses may also have an impact on a strategic level in a service design leadership perspective by influencing the overall scope and direction at the corporate level.

\section{Related Research Context}

The service design method AT-ONE described above formed the basis for the service design experience of the industry partners who are interviewed in this study. Four industry partners have been involved in the project. Two of these have been involved throughout the whole period of three years. These two organizations are an insurance company and a national lottery company. Five representatives (informants) from these two service organizations were interviewed. These interviews form the basis for the data presented below. The informants are numbered 1-5. Informants 1 and 2 represent organization A, while informants 3, 4 and 5 represent organization B. All informants have participated in each of the AT-ONE workshops 
at least once.

The industry partner informants all have a leadership role within innovation or marketing, and they all have some level of management education. None of them were trained as a professional designer. However, four out of five have experience in working with designers, either graphic designers or interaction designers. Working with service designers was novel for all of them.

\section{Data Presentation and Analysis}

Four key areas emerged as common among the interviewed industry partners in relation to the strategic use of service design in a collaborative process of shaping innovative services. The key areas are a) multi-disciplinary collaboration, b) visualization, c) service perspective vs. product perspective and d) awareness of the value of service design through experience. These are now addressed.

\section{Multi-disciplinary Collaboration}

Overall, the interviews with industry partners and observations by author show that the multidisciplinary collaboration between service designers and industry partners that took place at the AT-ONE workshops resulted in new insights about the value of combining these competences. For the industry partners, this insight was shaped by the outside-in view and the expertise that the designers represented as well as by the experience of working together with colleagues from other departments within the organization.

Collaborating across departments in their organizations helped the industry partners perceive the organization's service offering from a holistic, cross-departmental perspective by using the service journey in the process of developing new or improved services. One of the participants expressed this cross-departmental experience by stating, "In our organization we are so far apart and processes like this help us see the same thing" (Informant 1). The process of developing the service journey from the customer's point of view and the crossdepartmental co-operation made the service providers' participants aware of their own internal processes and how each of them affects the total customer experience. This is important because, as another informant expressed it, "They (the customers) see it (the service offering) holistically and do not care which departments that made one thing or another" (Informant 5). In addition to the aspect of internal multi-disciplinary and cross-departmental collaboration, adding the expertise of service designers to the team helped the service organizations to "see the same thing", as expressed by one informant. It also supported their understanding of their service offering through building experience of a holistic, customer-centric view. Mapping all touchpoints in a joint process helps form a common understanding of what happens at the different touchpoints from the customers' point of view. The mapping process, thereby, provides a basis for potential service innovations at each touchpoint.

Regarding the relationship between design and innovation, one of the informants said that "bringing in additional expertise gives an entirely different dimension" because "designers find insight in a slightly different way than perhaps the traditional analysts" (Informant 5). Another informant pointed to designers' ability to derive insights through observation. (Informant 2). Designers seem to collect a different type of market insight by their observational and empathetic skills and the way they 'translate' this insight into new or improved service ideas.

The value of multi-disciplinary collaboration between business and service designers, as experienced at the AT-ONE workshops, was also highlighted by one of the informants as 
follows:

It is when the expertise of the organization and the expertise of designers work together, that's when you get it out - the 'gold'. It is much more serendipitous that you get the 'gold' if they work separately. (Informant 3).

The point that it is more likely that valuable new ideas arise when organizations and service designers collaborate than when working separately is important to notice for both parts. From a service designer's perspective, Løvlie at live|work comments that clients bring many ideas to the table during an innovation process. He states that "ideas already exist in organizations. They have just never been seen or heard or had the chance to grow."

Despite the fact that the industry partners valued the contribution of service designers, it was also stressed that leaving service designers on their own in the conceptualizing phase of the service innovation process is not recommended. Some of the informants felt that designers, in general, might not always be as empathetic to the industry partner's (client's) challenging situations as they were to end-users' needs. This situation was also touched upon in the interview with Løvlie. He reflected that "a lot of designers just aren't good enough at being really empathetic with the clients' business drivers" and that they do not always understand the pressure that clients have in a challenging market.

Service designers need to understand two kinds of customer perspectives. They need to be customer-centric both towards end-users and towards their clients' situation when developing service innovations. In response to being asked about the core competence of service designers at the front end of a service innovation process, Informant 3 made a point of the importance of service designers being able to extract knowledge and insight from both client and customer, the ability to analyze this insight, and to transform it into services that respond to the needs that are there - both from a customer perspective and from the business point of view.

To obtain customer insight, service designers may use methods that differ from those of market researchers. One of the informants pointed to the fact that they had "tons of data about the customer". However, the informant had learned that service designers "have a different humility about what it means to know the customer" (Informant 3). Service designers are aware that to understand the customer, one has to do more than read reports: one has to get out there to observe and talk to the customer, according to the informant, who adds this: "I think business people are aware of this too; we just do not do it" (Informant 3).

\section{The Value of Visualization}

The ability to visualize problems, ideas and concepts was highlighted by all industry partner interviewees as one of the most valuable competences of service designers. In the AT-ONE workshops, visualization took the form of sketching by hand, while the designers further developed the concepts by using techniques like visual storytelling and visual evidencing (See e.g. Diana, Pacenti, \& Tassi, 2010). These techniques are used to facilitate a common understanding of the customer's experience of the service offering at the different touchpoints during a customer journey.

The importance of visualizing ideas was regarded as central. Firstly, visualization allows for a common understanding of an issue or idea as opposed to an oral or written report of which each individual creates their own unique understanding. One of the informants 
pointed out that "the same story in image and text will give different interpretations" (Informant 5).

Secondly, visualization of a problem or new service idea may help to explain and sell the message internally in the organization and get it across to decision-makers at different levels. Service designers' visual communication skills were commented on by several of the leaders as important to enable abstract service ideas to be communicated to internal stakeholders. Some of the informants even adopted the visualization technique in their own 'show don't tell' way to enable sharing of ideas for further development based on mutual understanding and as a basis for decision making.

The importance of designers' sketching and visualization abilities in an innovation project was highlighted when the industry partners were asked how to utilize their experience of working with service designers if placed in a future role as a leader of an innovation project. One informant gave the following key comment:

I certainly would have included them (designers) early in the process. I think I also would have included them far into the process. They would come to be central early in the process to bring out the ideas, to inspire the creative discussions and to help to illustrate/visualize. I had not done that before (participating in the AT-ONE workshops) (Informant 2).

At the front end of innovation, visual communication skills are particularly valuable in order to reach a shared viewpoint to enable further development of the idea into new services, whether incremental or radical. One of the informants expressed the value in terms of the way a sketch immediately triggered a discussion and made it possible to make corrections until the proposed service offering was satisfactorily described (Informant 2).

\section{Towards a Service Perspective}

By involving designers in 'real life' briefs from service organizations, an exchange of knowledge, methods and tools took place between the participants. Participants representing the service organizations stated they had gained new insights that transformed their view on what it means to be user-centric. This new insight also changed their attitudes towards seeing their service offerings as holistic service journeys with a multitude of touchpoints versus seeing their offering as a 'single product'. It remains to be seen how these attitudes may be translated in the organizations at a strategic level. This is the scope of a possible future study.

When asked how service design contributes to service providers' capacity to make use of design strategically at the front end of innovation, one of the informants explained that thinking of the offering in a service-oriented perspective - as opposed to a product-oriented perspective - made him change from viewing the service offering as a single product to a more holistic process with several touchpoints (Informant 4).

The CEO of one of the industry partners participating in the AT-ONE project is particularly aware of the value of being customer-centric, and one of the informants explained this as follows:

Extreme customer orientation came in as a term for the entire organization in a manner to be customer-oriented. Traditionally, we have probably been very 'product-oriented' and probably still are in some milieux, but we have run projects with the kind of innovation processes as we do with AT-ONE in milieux that are 'product'-focused and you see that they turn around, 
there is a change in attitude (towards a more customer-oriented service perspective) (Informant 2).

This shift in orientation from the product to the consumer is in line with the S-D logic (Vargo \& Lusch, 2004). However, to be truly customer-oriented may be a challenge for many organizations (Edvardsson, et al., 2006). Several of the informants pointed to this fact about their own organizations. Their impression was that, within their organizations, being customer-oriented sometimes meant selling as much as possible to customers to achieve their own personal budget targets more than being empathetic to the customer's real needs.

Seeing the service offering from the customer's point of view may be easier for outsiders like, for example, professional service designers than insiders in service organizations. This reflection was made by several of the informants, with one of them saying, "Service designers do not have biased attitudes and views on 'how we do things here" (Informant 1). Thereby, service designers help service providers see their service offerings' different touchpoints from the customer's point of view instead of from their own internal point of view. To empathize with others and see the customer's needs from the customer's own perspective and context is a core skill for designers (Junginger, 2007).

In a reply to a question of whether or not being customer-focused meant the same internally, before and after co-operating with service designers, one informant's comment may serve as an example of a general opinion that was expressed:

Since we started the AT-ONE process, and started working with live|work, being customerfocused has become very much 'top of mind' by everybody in a slightly different way than before. One has become even more motivated to be customer-focused (Informant 2).

Such a comment refers to having a customer-centric outside-in perspective rather than an internal inside-out perspective. One of the informants summarized the experience of working with service designers by stating that

One has certainly become more aware of the fact that unless our service offerings are developed from a customer-centric view, we can forget being in this market in the future (.....) It is an awareness that forms a basis for innovation (Informant 1).

Drawing on the change in attitude towards a more service-oriented perspective, as expressed by the informants, it may be argued that service design can be viewed as a "tool" to help service organizations become truly customer-oriented and innovative.

\section{Awareness of the Value of Service Design through Experience}

Service design was unknown to all of the industry informants before their participation in the AT-ONE project. For this reason, initially, the need for this kind of competence was not seen. When asked what prevented organizations from using designers and design methods in the development of service innovations, one of the informants argued that there were two main points. One was the resources (money and time) available and the other was a lack of understanding and knowledge about the value of using service designers (Informant 5). This informant also said that if one asks people where the designer belongs in an organization, most often the answer will be that it is in a mercantile environment working on catalogues, web-sides, prints and other work traditionally done by designers. Another informant 
underpins this: "We have some designers, but they are placed in the marketing department and are thinking in terms of advertising brochures and stuff like that" (Informant 1).

According to several of the workshop participants, a transformation in attitude regarding the strategic use of service design takes place when experiencing what service design contributes to the innovation process by challenging their own traditional way of thinking. However, at the same time, as this challenge is appreciated by the industry partners, the project leader, Clatworthy, argues that "industry partners want out of the box thinking, but evaluate the ideas within the box."

It was pointed out by several of the industry partners that, in business, service design is a quite unfamiliar competence and, thereby, not valued as one organizations are willing to pay for as with others, like advertising. This attitude corresponds with a statement from Clatworthy: "To understand design I think you have to work with a designer - which is a real disadvantage of design (...) it is only the companies that start (using design) that realize its benefits." From the service designer's point of view, the understanding is similar, as Løvlie states: "I think it is really hard for leaders to understand the potential of design because you kind of have to experience it to understand it." What is needed is that leaders are actively involved in processes of better understanding and appreciating the importance of design as part of their strategic resources for better meeting customers' needs.

\section{Discussion and Implications}

The results of this experimental research may be summarized according to four main insights drawn from the literature, the AT-ONE workshop process, the observational studies and the qualitative interviews. The four insights are 1) multidisciplinary collaboration and crossdepartmental perspectives may facilitate user-centric service innovations, 2) visualization helps allows for a common understanding of ideas and helps in getting the ideas across to decision-makers, 3) working with design professionals may influence clients' attitude towards seeing their service offering as a holistic service journey with a number of related touchpoints rather than as a 'single product' and 4) service design may be understood, strategically, by leaders of service-oriented organizations through collaboration with designers. These insights correlate with the author's experience as a non-designer working as a design manager on service design projects. From a design management view, the insights point to possible themes for discussion and implementation in service design at the front end of service innovation. They cannot be extrapolated all contexts, yet they raise themes for further investigations within actual contexts of implementation; this was not the focus of this study.

\section{1) The intersection of multi-disciplinary competences and collaboration in design and business facilitates service innovation.}

On the basis of this exploratory and micro-level study, it can be argued that a combination of knowledge, skills, methods and approaches in service design and service organizations generates a broader base for service innovation in the intersection of design and organizational leadership. A statement from one of the industry informants about getting 'the gold' when the expertise of designers and the expertise of the organization work together may serve to underline this argument. This is consistent with Gloppen's (2010) argument that a synthesis of design and business competences contributes to shaping service innovations and forms the basis for a service design leadership approach. In the collaborative service innovation process, business people may come up with ideas on an equal basis with those of designers. The industry partners participating in AT-ONE consider multi-disciplinary 
collaboration to be valuable, both in terms of combining design and business competences as well as by collaboration between departments in the innovation process.

Although service designers and service providers share a common interest in obtaining business objectives, their approaches may be different. Synthesizing these approaches, thus, enables a more integrated and holistic approach to developing service innovations. According to Brown (2008), designers combine user needs with business strategy in order to create customer value. However, service providers perceive service designers as sometimes being more empathetic to end-users' needs than to their own strategic limitations and requirements as clients.

The study indicates that bringing different competences together at the front end of the innovation process improves the shaping of service innovations. The 'gold' that one informant referred to may be found in the intersection of design and business competences. However, just as "good design does not emerge by accident, but as the result of a managed process" (Bruce \& Bessant, 2002, p. 38), service design leadership too comes into play at both operational and strategic corporate levels (Gloppen, 2009).

Understanding and taking advantage of the different kinds of customer insights and approaches in design and business is vital for how design management on the corporate level may contribute to service innovations. The ability to extract and analyze knowledge and insights from both client and customers into valuable services was highlighted by service providers taking part in the AT-ONE project as important contributions from service designers. On the corporate level, service design leadership connects the disciplines and areas of practice in design and business to enable shaping innovative services based on a customercentric perspective.

The five lenses that form the basis of the AT-ONE project provide a basis for a common understanding between service designers and industry partners. For service designers, this means that "our clients understand the space in an intelligent way so we can have good conversations with them", as Løvlie from live|work said when asked about the potential value of industry partners (clients) using the AT-ONE lenses as a framework for a design brief. For design leadership at the corporate level, this provides an opportunity for a holistic basis for design of service innovations. However, to take advantage of the AT-ONE framework in a service design leadership perspective may be argued to demand knowledge of design as well as of business strategy in a service context. This may be a challenge, as not many people have yet established a body of knowledge in this intersection. A good workshop facilitator is therefore important, as commented upon by the industry participants.

\section{2) Visualization of imagined service ideas and concepts enable mutual understanding and the} further development of service innovations.

The industry participants in AT-ONE highlighted designers' visualization skills in enabling mutual understanding of ideas to form a basis for further development of potential service innovations. This study shows that having the relevant internal departments participate in workshops with service designers helps develop this shared understanding as well as how each department internally may do their job as part of the whole system of touchpoints experienced by the customer. The 'service blueprint' made an important basis for this shared understanding in how a customer's 'service journey' was visualized.

The informants unanimously agreed on the value of service designers in helping conceptualize and visualize abstract new service ideas for a wide range of stakeholders. This resonates with studies by other service design researchers (Diana, et al., 2010; Kimbell, 2010; 
Kimbell \& Seidel, 2008). The ability of designers to synthesize different inputs and customer needs into imagined possibilities - and visualize this imagined service concept - streamlines service design leadership by achieving a common understanding as the basis for developing new or improved service offerings.

3) Collaboration with service design professionals may initiate a transformational process within service organizations towards a service perspective as a strategic approach.

A service perspective as a strategic approach focuses on adopting a customer perspective to create coherent service offerings in the form of a service journey with multiple touchpoints where each point is designed with the aim of being perceived as valuable by customers or consumers. This study shows that collaborating with service designers changes the attitude of what it means to be truly customer-oriented. This change in attitude takes place by seeing the service offering from a customer-centric point of view instead of from an organization-centric point of view. The act of being customer-oriented in a way that is seeing the service offering through customers' lenses versus through the lens of the service organization may constitute an internal transformation in service organizations towards a service perspective as a strategic approach.

Working with service designers gave the industry participants in the AT-ONE workshop new ways of approaching future strategy. Firstly, this was accomplished via a shift to a user perspective that sees the service offering from the customers' point of view. Such a perspective may influence a future understanding of the service approach (Edvardsson, et al., 2006). Secondly, collaborating with service designers made them aware of how a service perspective is different from a product perspective (Vargo \& Lusch, 2004). When one adopts a service-dominant logic, the result may be a change in corporate strategy that requires rethinking within the field of design management at the corporate level in service organizations.

For design management at the corporate level, the central implication of a servicecentered view as opposed to a goods-centered view is the transformation in attitudes towards a more holistic perspective. Part of what formed the AT-ONE industry partners' transformation was the influence of service designers' view of a service offering as a journey over time - with a range of touchpoints. This study shows that taking on a customer-centric, holistic perspective influences the internal organization towards more co-operation and understanding between departments in the process of designing innovative services. Realizing a service perspective as a strategic approach implies we need to focus on designing services from a customer's point of view.

Customers see a service provider's service offering as a whole, as pointed out by one of the informants. Consequently, it is preferable that relevant departments operate on the same level of understanding of what kind of service experience is desirable during the total service journey. This aligns well with arguments made by Bitner et al. (2008) for using service blueprinting as a method for service innovation with respect to the need to take on a crossdisciplinary, cross-functional view. However, this demands a service design leadership approach that takes on a holistic view by looking at the user experience as an entity as well as in detail.

4) Experience in collaborating with service designers creates awareness of the value of the strategic use of service design in an innovation process.

In relation to business strategy, several of the AT-ONE industry partners argued that within 
business development and innovation, it is traditionally not natural to think there is a need for a designer in the same way that there is a need for a business developer. The main reason for this attitude was the lack of awareness of how service designers may contribute to an innovation process. Close collaboration between service designers and leaders in service organizations will probably modify this view. As this study shows, such change is possible when leaders in service organizations experience the value of service design by actually cooperating with service designers in the process of shaping innovative services.

Several of the learning experiences the interviewees highlighted about collaborating with service designers resonate with research on how design matters for management (Boland $\&$ Collopy, 2004). These include the ability to make intangible ideas visible, seeing a problem from a user-centric or customer-centric point of view and the different orientation designers bring to a design project (Michlewski, 2008). For the industry partners, the awareness of the value of the strategic use of service design and the knowledge and learning obtained by working in collaboration with service designers has resulted in further use of service design in developing new service innovations. For example, the insurance company has continued to collaborate with service designers at the strategic as well as operational level. One result is a youth packet that combines insurance and banking services. These services used to be run by two separate business units with different customer approaches based on an organizationcentric view. Taking on a customer-centric coherent view on banking and insurance experience and adopting a customer perspective that goes beyond organizational department boundaries (silos) as a guiding principle in the development process resulted in a new combined service package. This new service offering sold more in two weeks than their previous offering to the young adults did in one year. Service organizations' return on investment in the use of professional service designers may therefore be argued to be an important source to enhance competitiveness and growth, which in turn indicates that strategic use of service design may benefit leaders in service organizations in their strategy development.

An important part of service design leadership is how to create service innovations that are perceived as valuable by customers while at the same time contributing to the triple bottom line - economic, environmental and social - (Løvlie, et al., 2008) in service organizations. To enable this, leaders need to understand the value of each design discipline and how each discipline may contribute in developing every touchpoint of the total service offering as well as the overall user experience. This is important in order to manage the bridging of design and business skills for future competiveness and growth. A customercentric service perspective challenges leaders to rethink and re-evaluate how service innovation impacts their organization's strategic market positioning. By being concerned with 'what might be', the abductive nature of both strategic thinking and design thinking is relevant to realize the desired future, competitive position.

The front end of innovation is where tomorrow's value for customers and organizations is being shaped today. The strategic use of service design, and the way design and business resources are integrated and managed at the corporate level, helps shape desirable service innovations for tomorrow.

\section{Conclusions}

To date, relatively few studies address design management in the emerging field of service design. Shaping holistic service innovations requires an organization to go beyond organizational department boundaries (silos) in order to develop seamless service experiences 
for users. This demands that design management be placed at a corporate level, that is not just at a departmental level or local level, but at a higher strategic level that serves to emphasize future direction. This is needed in order to take advantage of the strategic value and competitive advantage of service design. In this context, the term service design leadership is used to place strategic design management at the leadership level in service organizations.

While design is increasingly appreciated as a strategic tool in business, how leaders relate to the value of service design at the important front end of service innovation is not well covered in research. This study explored the core competences and value of service designers as perceived by leaders in service organizations in an exploratory, collaborative workshop context. The workshops were based on the AT-ONE methodology, which provides a broad and structured framework for developing design-based service innovations in multi-disciplinary teams. The findings of several years of work provide four main insights as to the value of using service designers as well as the potential of synthesizing design and business competences to enhance the potential for new or improved services. These findings may benefit leaders in service organizations if implemented on the strategic level.

Although service design is a topic in circulation among scholars and designers, the term was unknown among the industry partners in the study. They were also unfamiliar with what service designers may contribute to business. For service designers, the implications of this market situation of such unfamiliarity are a challenge and require good cases that demonstrate the value of service design in business. For service organizations, it is important that their own offering is seen from the same point of view as service designers, namely that of users. However, service designers need to have a mindset that empathizes with users while at the same time being aware of corporate challenges.

In order to design service innovations that are perceived as valuable by the user, there is a further need for design management at the corporate level to adopt a leadership approach that synthesizes the most relevant competences from design and business. For design management, this is a matter of not only facilitating mutual understanding to optimize collaboration between design and business. It is also one of enabling the different subdisciplines in design to collaborate and contribute to service innovations. The complexity, multiple touchpoints and time factor involved in designing services make a holistic view on service design leadership all the more central and important in the response to meeting future challenges for business in the service industry.

\section{Acknowledgements}

AT-ONE is funded by the Research Council of Norway in collaboration with industry. My thanks go to the industry partners, the AT-ONE project leader and researcher Simon Clatworthy, and the service designer Lavrans Løvlie. For research inputs, critique and suggestions, my thanks go to Prof. Andrew Morrison, Oslo School of Architecture and Design, and Prof. Alison Rieple, University of Westminster.

\section{Judith Gloppen}

PhD candidate

The Oslo School of Architecture and Design

Email address: Judith.Gloppen@aho.no 


\section{References}

Bessant, J., \& Maher, L. (2009). Developing radical service innovations in healthcare - the role of design methods. International Journal of Innovation Management, 13(4), 555568.

Bitner, M. J., Ostrom, A. L., \& Morgan, F. N. (2008). Service blueprinting: a practical technique for service innovation. California Management Review, 50(3), 66-94.

Boland, R. J., \& Collopy, F. (2004). Design matters for management. In R. J. Boland \& F. Collopy (Eds.), Managing as designing (pp. 3-18). Stanford: Stanford University Press.

Borja De Mozota, B., \& Kim, B. Y. (2009). Managing design as a core competency: lessons from Korea. Design Management Review, 20(2), 66-76.

Boztepe, S. (2007). User value: competing theories and models. International Journal of Design, 1(2), 55-63.

Brown, T. (2008). Design thinking. Harvard Business Review, 86(6), 84-92.

Brown, T. (2009). Change by design: how design thinking transforms organizations and inspires innovation. New York: HarperCollins Publishers.

Bruce, M., \& Bessant, J. (2002). Design in business: strategic innovation through design. New York: Financial Times/Prentice Hall.

Clatworthy, S. (2008). Innovations in service experiences: the AT-ONE method. Paper presented at the 6th Design and Emotion Conference. October 6-9, Hong Kong.

Clatworthy, S. (2010). Service innovation through touch-points. the AT-ONE touch-point cards. Paper presented at the ServDes. Service design and innovation conference. The 2nd Nordic conference on service design and service innovation. Linköping, Sweden. 1-3 December.

Clatworthy, S. (forthcoming). Service innovation through touch-points: development of an innovation toolkit for the first stages of new service development. International Journal of Design. Special issue on designing for services.

Cooper, R., Junginger, S., \& Lockwood, T. (2010). Design thinking and design management: a research and practice perspective. In T. Lockwood (Ed.), Design thinking. Integrative innovation, customer experience, and brand value (pp. 57-63). New York: Allworth Press.

Diana, C., Pacenti, E., \& Tassi, R. (2010). Visual tools to design. about the role of visualization techniques for service design. Design Research Journal(1), 49-55.

Edvardsson, B., Gustafsson, A., Kristensson, P., Magnusson, P., \& Matthing, J. (Eds.). (2006). Involving customers in new service development. London: Imperial College Press.

Edvardsson, B., Gustafsson, A., \& Roos, I. (2005). Service portraits in service research: a critical review. International Journal of Service Industry Management, 16(1), 107121.

Ghauri, P. N., Grønhaug, K., \& Kristianslund, I. (1995). Research methods in business studies: a practical guide. Hertfordshire: Prentice Hall. 
Gloppen, J. (2009). Perspectives on design leadership and design thinking and how they relate to European service industries. Design Management Journal, 4(1), 33-47.

Gloppen, J. (2010). Service design leadership. Design Research Journal (1), 42-48.

Grönroos, C. (1994). From scientific management to service management.: a management perspective for the age of service competition. International Journal of Service Industry Management, 5(1), 5-20.

Gummesson, E. (2007). Exit services marketing - enter service marketing. Journal of Customer Behaviour, 6(2), 113-141.

Haberberg, A., \& Rieple, A. (2008). Srategic management: theory and application. New York: Oxford.

Holmlid, S. (2007). Interaction design and service design: expanding a comparison of design disciplines. Paper presented at the Nordes 2007. Design Inquiries. 2nd Nordic Design Research Conference. Stockholm, May 27-30.

Johansson, U., \& Woodilla, J. (2009). Towards an epistemological merger of design thinking, strategy and innovation. Design Research Journal (2), 29-33.

Junginger, S. (2007). Learning to design: giving purpose to heart, hand and mind. Journal of Business Strategy, 28(4), 59-65.

Kimbell, L. (2010). Designing for services in science and technology-based enterprises. In T. Inns (Ed.), Designing for the 21st Century. Interdisciplinary methods and findings (Vol. 2, pp. 55-66). Farnham: Gower Publishing.

Kimbell, L., \& Seidel, V. P. (Eds.). (2008). Designing for services - multidisciplinary perspectives: proceedings from the exploratory project on designing for services in science and technology-based enterprises. Oxford: University of Oxford, Säid Business School.

Kotler, P., \& Rath, G. A. (1984). Design: a powerful but neglected strategic tool. Journal of Business Strategy, 5(2), 16-21.

Kvale, S. (1996). Interviews: an introduction to qualitative reseach interviewing. Thousand Oaks, Ca.: Sage.

Liedtka, J. (2000). In defense of strategy as design. California Management Review, 42(3), 830.

Lockwood, T. (2010a). Transition: becoming a design-minded organization. In T. Lockwood (Ed.), Design thinking: integrating innovation, customer experience, and brand value (pp. 81-95). New York: Allworth Press.

Lockwood, T. (Ed.). (2010b). Design thinking. integrating innovation, customer experience, and brand value. New York: Allworth Press.

Lusch, R. F., \& Vargo, S. L. (Eds.). (2006). The service-dominant logic of marketing: dialog, debate, and directions. Armonk, N.Y.: M.E. Sharpe.

Løvlie, L., Downs, C., \& Reason, B. (2008). Bottom-line experiences: measuring the value of design in service. Design Management Review, 19(1), 73-79.

Mager, B. (2004). Service design: a review. Köln: Köln International School of design. 
Martin, R. (2009). The design of business: why design thinking is the next competitive advantage. Boston: Harvard Business Press.

Meroni, A., \& Sangiorgi, D. (2011). Designing for services: Gower.

Michel, S., Brown, S. W., \& Gallan, A. S. (2008). An expanded and strategic view of discontinuous innovations: deploying a service-dominant logic. Journal of the Academy of Marketing Science, 36(1), 54-66.

Michlewski, K. (2008). Uncovering design attitude: inside the culture of designers. Organization Studies, 29(3), 373-392.

Miettinen, S., \& Koivisto, M. (Eds.). (2009). Designing services with innovative methods. Helsinki: University of Art and Design Helsinki.

Normann, R. (2007). Reframing business: when the map changes the landscape. Chichester: Wiley.

Osterwalder, A. (2004). The business model ontology: a proposition in a design science approach. Unpublished PhD dissertation, Ecole des Hautes Etudes Commerciales de l'Universite'de Lausanne, Lausanne.

Osterwalder, A., \& Pigneur, Y. (2010). Business model generation: a handbook for visionaries, game changers, and challengers. Hoboken, N.J.: Wiley.

Perks, H., Cooper, R., \& Jones, C. (2005). Characterizing the role of design in new product development: an empirically derived taxonomy. The Journal of Product Innovation Management, 22(2), 111-127.

Pine, B. J., \& Gilmore, J. H. (1999). The experience economy: work is theatre \& every business a stage. Boston, Mass.: Harvard Business School Press.

Robson, C. (2002). Real world research: a resource for social scientists and practitionerresearchers (2nd ed.). Oxford: Blackwell.

Rylander, A. (2009). Design thinking as knowledge work: espistemological foundations and practical implications. Design Management Journal, 4(1), 7-19.

Shostack, G. L. (1984). Designing services that deliver. Harvard Business Review, Vol. 62(1), 133-139.

Stickdorn, M., \& Schneider, J. (Eds.). (2010). This is service design thinking: basics, tools, cases. Amsterdam: BIS Publishers.

Turner, R., \& Topalian, A. (2002). Core responsibilities of design leaders in commercially demanding environments. Paper presented at the Design Leadership Forum. July, London.

Vargo, S. L., \& Lusch, R. F. (2004). Evolving to a new dominant logic for marketing. Journal of Marketing, 68(January), 1-17.

Vargo, S. L., \& Lusch, R. F. (2008). Service-dominant logic: continuing the evolution. Journal of the Academy of Marketing Science, 36(1), 1-10. 
Judith Gloppen The Strategic Use of Service Design for Leaders in Service Organizations

\section{Endnotes}

${ }^{1}$ The Design Management Institute was founded in 1975. It is a 'non-profit' organization with members from both design and business as well as research from these disciplines. For further information, please see: http://www.dmi.org/dmi/html/aboutdmi/aboutdmi s.htm. Retrieved July 21, 2010.

${ }^{2}$ http://www.dmi.org/dmi/html/aboutdmi/design_management.htm. Retrieved July 12, 2010.

${ }^{3}$ On sdn, see http://www.service-design-network.org. Retrieved October 19, 2010.

${ }^{4}$ Details of the 1st CADMC conference can be found at: http://www.cadmc.org/. Retrieved July 22, 2011.

${ }^{5}$ For further information about the AT-ONE project, see Clatworthy (2008) and http://www.serviceinnovation.org/?page $\mathrm{id}=2$.

${ }^{6}$ The design process. (n.d.). Retrieved July 2, 2010 from http://www.designcouncil.org.uk/about-design/How-designerswork/The-design-process/ 